\title{
Dependence of Selected Water Quality Parameters on Flow Rates at River Sites in the Czech Republic
}

\author{
Eduard Hanslík ${ }^{* 1}$, Diana Marešová ${ }^{2}$, Eva Juranová ${ }^{3}$, Radek Vlnas ${ }^{4}$ \\ ${ }^{1}$ Department of Radioecology, T. G. Masaryk Water Research Institute, Podbabská 2582/30, Prague, \\ Czech Republic \\ e-mail: eduard hanslik@vuv.cz \\ ${ }^{2}$ Department of Radioecology, T. G. Masaryk Water Research Institute, Podbabská 2582/30, Prague, \\ Czech Republic \\ e-mail: diana maresova@vuv.cz \\ ${ }^{3}$ Department of Radioecology, T. G. Masaryk Water Research Institute, Podbabská 2582/30, Prague, \\ Czech Republic \\ e-mail: eva juranova@,vuv.cz \\ ${ }^{3}$ Faculty of Science, Institute for Environmental Studies, Charles University, Ovocný trh 3-5, Prague, \\ Czech Republic \\ ${ }^{4}$ Department of Radioecology, T. G. Masaryk Water Research Institute, Podbabská 2582/30, Prague, \\ Czech Republic \\ e-mail: radek vlnas@,vuv.cz
}

Cite as: Hanslík, E., Marešová, D., Juranová, E., Vlnas, R., Dependence of Selected Water Quality Parameters on Flow Rates at River Sites in the Czech Republic, J. sustain. dev. energy water environ. syst., 4(2), pp 127-140, 2016, DOI: http://dx.doi.org/10.13044/j.sdewes.2016.04.0011

\begin{abstract}
The paper analyses dependence of water quality parameters on flow rates at several sites in the Vltava River catchment in the Czech Republic. The presented results indicate that at the monitored sites, concentrations of nitrates, suspended solids and dissolved oxygen are in direct relation to flow rate. Temperature has an inverse relationship to flow rate. Other parameters show various relationships to flow rate at individual monitored sites or do not show any statistically significant relations.
\end{abstract}

\section{KEYWORDS}

Water quality, Flow rate, Point pollution source, Nonpoint pollution source, Drought, Flood.

\section{INTRODUCTION}

Recently, the potential of climate change impact on surface water quality is being increasingly recognised. Current studies have shown that water quality can be directly influenced by several related mechanisms on both a short and long-term basis. It is, for instance, the influence of increase in air temperature, changes in hydrologic characteristics (decrease in dilution capacity of pollution from point sources during low flow rates), terrestrial factors (changes of vegetation and soil structure) or water use (increased water demand, higher need of cooling water) [1]. All of these changes could cause shifts in energy demand, vulnerabilities of supply and risks for energy infrastructure [2].

The modelled future scenarios reveal that potential future changes in the climatic regime are likely to modify hydrologic and nutrient fluxes considerably. Shrestha [3] shows that simulated nutrient loads match the dynamics of the future runoff for both nitrogen and phosphorus closely. However, nutrient concentrations could decrease due

\footnotetext{
${ }^{*}$ Corresponding author
} 
to the higher rate of runoff increase. Johnson [4] presents the results of catchment modelling in 20 large basins in the United States (US). Changes in pollutant loads follow a pattern similar to streamflow but with increased variability. Ensemble mean results suggest that by the mid- $21^{\text {st }}$ century, statistically significant changes in streamflow and total suspended solid loads (relative to baseline conditions) are possible in roughly 30$40 \%$ of studied catchments. These proportions increase to around $60 \%$ for total phosphorus and total nitrogen loads.

The climate change scenario in Vlnas [4] for the studied area in the Czech Republic shows apparent changes in hydrological regime; especially decrease of average flows and their fluctuation. The study projects essential changes of outflow distribution during the year with more frequently occurring extreme phenomena - floods during the winter and droughts during summer and autumn [5].

Droughts are increasing in frequency and severity in many regions of the world due to climate change. The meteorological drivers of drought often cause subsequent hydrological effects such as reduced catchment runoff, river flows and lake levels. Hydrological drought may also result in significant changes in water quality [6]. It can cause a decrease in available water resources, which can render water resources useless for human needs and simultaneously damage the environment [7].

Caruso [7] observed the impact of summer drought which afflicted Otago region in New Zealand in 1998-19998. In the study, river ecosystems became significantly influenced by a number of time-spatially related impacts during low flow in the watercourse. These depended on the stream character in this region. Considerable impacts on water quality have been observed in many parameters, especially bacteria, nutrients, turbidity and dissolved solids. Other water quality parameters showed time-spatial characteristics comparable to any other year. They can even increase during particularly low flow rates. Indeed, the water quality in streams can deteriorate critically during longterm periods of low flows in combination with high temperatures. Hence, understanding the impact of drought on water quality is important [9]. For example, Vliet and Zwolsman [10] scrutinized impacts of summer drought on quality of water in the Meuse River in 1976 and 2003. Adverse influence was found for temperature, $\mathrm{O}_{2}$ concentration, eutrophication, macro-component concentrations and some heavy metals ( $\mathrm{Se}, \mathrm{Ni}$ a $\mathrm{Ba}$ ). In contrast concentrations of nitrates and several heavy metals $(\mathrm{Pb}, \mathrm{Cr}, \mathrm{Hg}$ and $\mathrm{Cd})$ were lower during low flow rate periods. However, the negative effects are considered predominant. In accord with possible increase of frequency and intensity of the water deficit associated with climate change, a decrease in economic and recreational potential of rivers can be expected, as a consequence of lower water quality. Authors further found that selected water quality parameters in drought periods worsen mostly due to optimal conditions for algal bloom, which include temperature, long detention time, high nutrient concentrations and lower dilution capacity for pollution from point sources.

Water flow and volume decreases during drought typically lead to increased salinity due to reduced dilution and increased concentration of mass. Temperature increases and enhanced stratification occur in some systems due to increasing air temperature and longer hydraulic residence times. This also enhances algal production, promotes toxic cyanobacterial blooms, and lowers dissolved oxygen concentrations. Where point sources of pollution were present, water quality generally showed deterioration due to less dilution, particularly for nutrients [7].

In summer season, increased water temperature can limit discharge cooling water from power plants or availability of high quality water for agricultural or household needs. Especially for drinking water supply, higher frequency of drought periods can become a serious threat, as threshold values for temperature or relevant parameters like 
$\mathrm{Cl}^{-}, \mathrm{F}^{-}, \mathrm{Br}^{+}, \mathrm{NH}_{4}^{+}$are exceeded. Difficulties to meet the legal requirement for drinking water are expected to occur at the observed site during long-term drought. Hence, restriction of point sources emissions will be needed during low flow periods to reduce the negative effects of drought on water quality [10].

In this study, influence of low flow rates on water quality is assessed on several examples of river sites, tributaries and the outflow of the Orlík Reservoir, which is located at the Vltava River in the Czech Republic. At these sites, changes in general parameters of the water quality were monitored:

- Temperature $(T)$;

- $\mathrm{pH}$;

- Dissolved oxygen $\left(\mathrm{O}_{2}\right)$;

- Chemical oxygen demand permanganate $\left(\mathrm{COD}_{\mathrm{Mn}}\right)$;

- Chemical oxygen demand dichromate $\left(\mathrm{COD}_{\mathrm{Cr}}\right)$;

- Biochemical oxygen demand (BOD5);

- Suspended solids (SS);

- Nutrients;

$\circ \quad$ Nitrate nitrogen $\left(\mathrm{N}-\mathrm{NO}_{3}{ }^{-}\right)$;

○ Ammonia nitrogen $\left(\mathrm{N}-\mathrm{NH}_{4}{ }^{+}\right)$;

- Total phosphorus $\left(\mathrm{P}_{\mathrm{T}}\right)$;

$\circ$ Phosphate phosphorus $\left(\mathrm{P}-\mathrm{PO}_{4}{ }^{3-}\right)$;

- Further quality parameters;

- Dissolved Solids (DS);

- Dissolved Inorganic Salts (DIS);

- Calcium $\left(\mathrm{Ca}^{2+}\right)$;

- Magnesium $\left(\mathrm{Mg}^{2+}\right)$;

- Potassium $\left(\mathrm{K}^{+}\right)$;

○ Chlorides $\left(\mathrm{Cl}^{-}\right)$;

○ Sulphates $\left(\mathrm{SO}_{4}{ }^{2-}\right)$;

- Qualitatively;

- Non-polar Extractive Substance (NES) a anion-active surfactants.

The assessed period was 1997-2013.

The aim of the study was to evaluate the relationship between the listed parameters and flow rates in days when the samples were taken. Furthermore, ratios of average parameter values during low and high flows were calculated, which enabled to assess the character of the pollution sources. Thanks to that, the study helps to identify critical water quality parameters during the dry season.

\section{METHODS}

In this study, the catchment of the Orlík Reservoir was assessed. The catchment was represented by sites at main reservoir tributaries (Vltava Hněvkovice, Lužnice Koloděje, Vltava Kořensko, Otava Topělec) and at the reservoir outflow (Vltava Solenice). These sites are displayed in Figure 1. Basic characteristics of the catchment, including a summary of discharges from point pollution sources according to [10,11], are shown in Table 1. The point pollution sources are most often the outflows from municipal waste water treatment plants and also releases of industrial waste waters. Nonpoint pollution sources in this region are predominantly represented by the runoff and wash out from the agricultural areas (see Figure 1).

Evaluated data sets including water quality and flow rate values were collected by the Czech Hydrometeorological Institute, Povodí Vltavy, State Enterprise and the ČEZ 
Group. All the monitored water quality parameters were observed at all the concerned river sites once in a month.

When assessing the relevancy of the relationship of the quality parameters on the flow rate in days of sampling, Spearman coefficient was used. The relationship was described with a power function:

$$
c_{i}=a \times Q_{i}^{b}
$$

where:

- $c_{i}$ is value of parameter in days of sampling [mg/l];

- $Q_{i}$ is average flow rate in days of sampling $\left[\mathrm{m}^{3} / \mathrm{s}\right]$;

- $a, b$ are power relation coefficients.

For the selected water quality parameters at sites at the main tributaries and the outflow of the Orlík Reservoir, the power relations were compared graphically.

M-day flow rate values were assumed from operating regulations of the Orlík Dam [12], and from records of the Czech Hydrometeorological Institute [13].

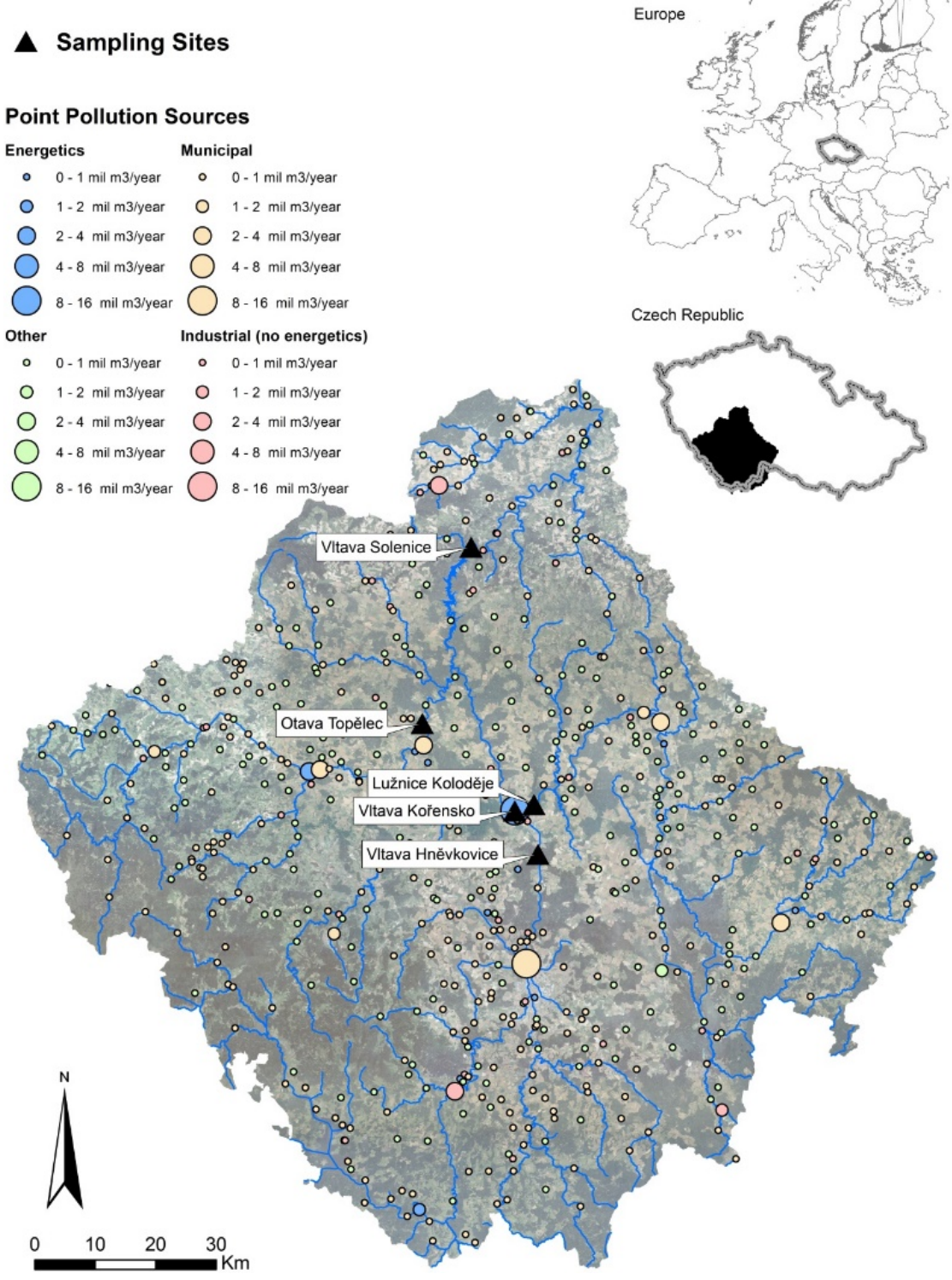

Figure 1. Map of sampling sites and the point pollution sources in the region 
In the assessed sites, the $Q_{70 \%}$ flow rates were determined as flow rates not exceeded for $70 \%$ days per year. The $Q_{70 \%}$ flow rates are:

- Vltava Hněvkovice - $15.5 \mathrm{~m}^{3} / \mathrm{s}$;

- Lužnice Koloděje $-10.1 \mathrm{~m}^{3} / \mathrm{s}$;

- Vltava Kořensko - $26.5 \mathrm{~m}^{3} / \mathrm{s}$;

- Otava Topělec - $11.8 \mathrm{~m}^{3} / \mathrm{s}$;

- Vltava Solenice $-40.9 \mathrm{~m}^{3} / \mathrm{s}$.

Then, average values of quality parameters corresponding to the flow rates lower than $Q_{70 \%}$ and higher than $Q_{70 \%}$ were calculated.

Table 1. Basic characteristics of the studied catchment, including a summary of discharges from point pollution sources ${ }^{*}$ in 2009 [11]

\begin{tabular}{|c|c|c|c|c|c|c|}
\hline & & & $\begin{array}{c}\text { Vltava } \\
\text { Hněvkovice }\end{array}$ & $\begin{array}{l}\text { Lužnice } \\
\text { Koloděje }\end{array}$ & $\begin{array}{l}\text { Otava } \\
\text { Topělec }\end{array}$ & $\begin{array}{l}\text { Vltava } \\
\text { Solenice }\end{array}$ \\
\hline \multicolumn{2}{|c|}{ Area of catchment } & {$\left[\mathrm{km}^{2}\right]$} & 3,869 & 4,234 & 3,840 & 12,062 \\
\hline \multicolumn{2}{|c|}{$\begin{array}{l}\text { Summary of discharges } \\
\text { from point pollution } \\
\text { sources }\end{array}$} & [million $\mathrm{m}^{3}$ ] & 35.1 & 22.4 & 28.3 & 93.8 \\
\hline \multicolumn{2}{|c|}{$\begin{array}{l}\text { Number of pollution } \\
\text { sources }\end{array}$} & & 146 & 153 & 179 & 506 \\
\hline \multirow{7}{*}{ Balance } & BOD & {$[\mathrm{t} / \mathrm{y}]$} & 201 & 229 & 164 & 631 \\
\hline & COD & {$[\mathrm{t} / \mathrm{y}]$} & 1,156 & 892 & 673 & 3,174 \\
\hline & SS & {$[\mathrm{t} / \mathrm{y}]$} & 241 & 238 & 175 & 819 \\
\hline & DS & {$[\mathrm{t} / \mathrm{y}]$} & 12,959 & 7,028 & 5,659 & 29,105 \\
\hline & $\mathrm{N}-\mathrm{NH}_{4}{ }^{+}$ & {$[\mathrm{t} / \mathrm{y}]$} & 81 & 73 & 69 & 232 \\
\hline & $\mathrm{N}_{\text {anorg }}$ & {$[\mathrm{t} / \mathrm{y}]$} & 211 & 208 & 165 & 676 \\
\hline & $\mathrm{P}_{\mathrm{T}}$ & {$[\mathrm{t} / \mathrm{y}]$} & 19 & 29 & 18 & 74 \\
\hline
\end{tabular}

* Sources discharging more than $500 \mathrm{~m}^{3} /$ month were included

\section{RESULTS AND DISCUSSION}

At the monitored sites (Vltava Hněvkovice, Lužnice Koloděje, Vltava Kořensko, Otava Topělec and Vltava Solenice), the relation between eighteen water quality parameters and flow rates was assessed using the power function. It was expected changes in pollution discharges from point sources to be small during the evaluated period 1997-2013. At the Vltava Hněvkovice site, a statistically significant correlation was found for eleven of the assessed parameters, of which seven parameters showed direct dependence $\left(\mathrm{O}_{2}, \mathrm{Mg}^{2+}, \mathrm{COD}_{\mathrm{Mn}}, \mathrm{COD}_{\mathrm{Cr}}, \mathrm{SS}, \mathrm{N}_{-N_{3}}{ }^{-}, \mathrm{pH}\right)$ and four inverse dependence $\left(T, \mathrm{~N}-\mathrm{NH}_{4}{ }^{+}, \mathrm{Ca}^{2+}, \mathrm{SO}_{4}{ }^{2-}\right)$ on flow rate. At the Lužnice Koloděje site, a statistically significant correlation was found for thirteen parameters, of which three parameters showed direct dependence $\left(\mathrm{SS}, \mathrm{N}-\mathrm{NO}_{3}{ }^{-}, \mathrm{O}_{2}\right)$ and ten parameters inverse dependence (DS, $T, \mathrm{pH}, \mathrm{BOD}_{5}, \mathrm{Ca}^{2+}, \mathrm{Mg}^{2+}, \mathrm{SO}_{4}{ }^{2-}, \mathrm{Cl}^{-}, \mathrm{P}_{\mathrm{T}}, \mathrm{P}_{-} \mathrm{PO}_{4}{ }^{3-}$ ). At the Vltava Kořensko site, a statistically significant correlation was found for seven parameters, of which five parameters showed direct dependence $\left(\mathrm{O}_{2}, \mathrm{SS}, \mathrm{N}^{-\mathrm{NO}_{3}}{ }^{-}, \mathrm{Mg}^{2+}, \mathrm{COD}_{\mathrm{Cr}}\right)$ and two parameters inverse dependence $(T, \mathrm{pH})$. At the Otava Topělec site, a statistically significant correlation was found for six parameters, of which two parameters showed direct dependence (SS, N-NO${ }_{3}{ }^{-}$) and four parameters inverse dependence $\left(\mathrm{N}_{-} \mathrm{NH}_{4}{ }^{+}, \mathrm{Cl}-\right.$, $\left.\mathrm{P}_{\mathrm{T}}, \mathrm{P}_{-} \mathrm{PO}_{4}{ }^{3-}\right)$. At the Vltava Solenice site, a statistically significant correlation was found for nine parameters, of which eight parameters showed direct dependence $\left(\mathrm{O}_{2}, \mathrm{COD}_{\mathrm{Mn}}\right.$, $\left.\mathrm{COD}_{\mathrm{Cr}}, \mathrm{SS}, \mathrm{N}-\mathrm{NO}_{3}{ }^{-}, \mathrm{P}_{\mathrm{T}}, \mathrm{DS}, \mathrm{BOD}_{5}\right)$ and one parameter showed inverse dependence $(T)$. 
The SS and $\mathrm{N}^{-\mathrm{NO}_{3}}{ }^{-}$parameters demonstrated direct dependence at all assessed sites. Relation of Non-polar Extractive Substance (NES) and anion-active surfactant concentrations to flow rates was not evaluated quantitatively because most concentration values were around detection limits of used analytical methods.

The above stated findings indicate that the concentrations of some monitored parameters decrease with rising flow rate. This implies that the contamination represented by these parameters originates from the point sources. The concentration in the river water depends on the actual flow rate in the stream - as the flow rises, the contaminants get more diluted.

On the other hand, some of the parameters show contradictory trends: with higher flow rate in the stream, higher concentration of these parameters can be measured in surface water. This indicates an influence of nonpoint pollution sources - in addition to the elevation of water levels in streams, precipitation can cause increased runoff and washout of contaminants, especially from agricultural areas.

The impact of current point pollution sources on assessed water quality parameters is the most significant at the Lužnice Koloděje site (ten parameters with inverse dependence). Water quality at the Vltavathe Hněvkovice and Vltava Kořensko sites is further influenced by increasing flowage of the upstream Lipno Reservoir during dry periods. In the Lužnice River, a considerable factor influencing the water quality is fish farming. Water quality at the Vltava Solenicesite is affected by the contribution of the Otava River and processes of water quality changes in the Orlík Reservoir. It is clear that nonpoint pollution sources also play a noticeable role, especially fertilization of agricultural land with nitrogen fertilizers.

In Figure 2-5, there are examples of graphical assessment of the relation between concentration and flow rate for $\mathrm{COD}_{\mathrm{Cr}},{\mathrm{N}-\mathrm{NO}_{3}}^{-}, \mathrm{N}_{-} \mathrm{NH}_{4}{ }^{+}$and $T$ parameters. In addition, the flow rate at the $70 \%$ level is also displayed in the graphs.

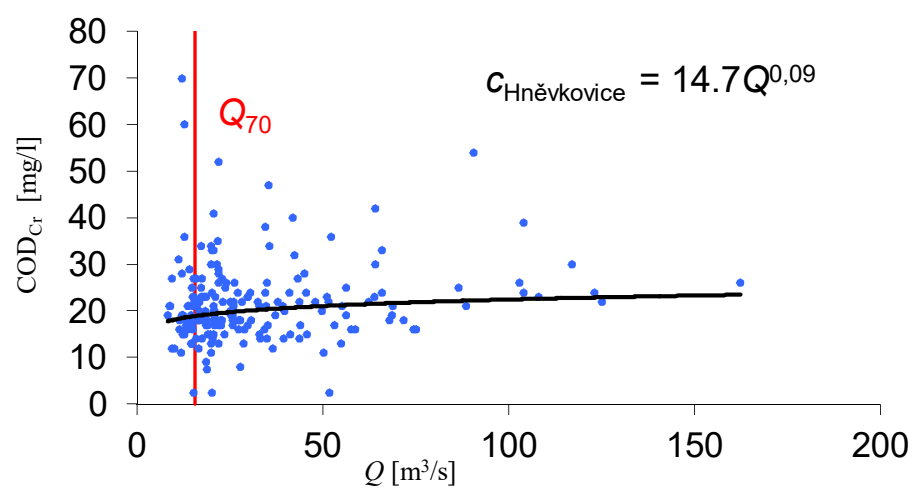

Figure 2. Relation between $\mathrm{COD}_{\mathrm{Cr}}$ and flow rate at the Vltava Hněvkovice site in 1997-2013

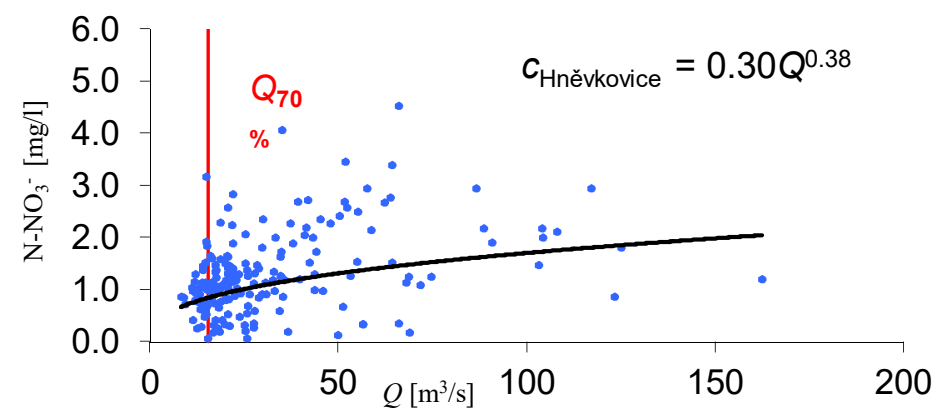

Figure 3. Relation between ${\mathrm{N}-\mathrm{NO}_{3}}^{-}$and flow rate at the Vltava Hněvkovice site in 1997-2013 


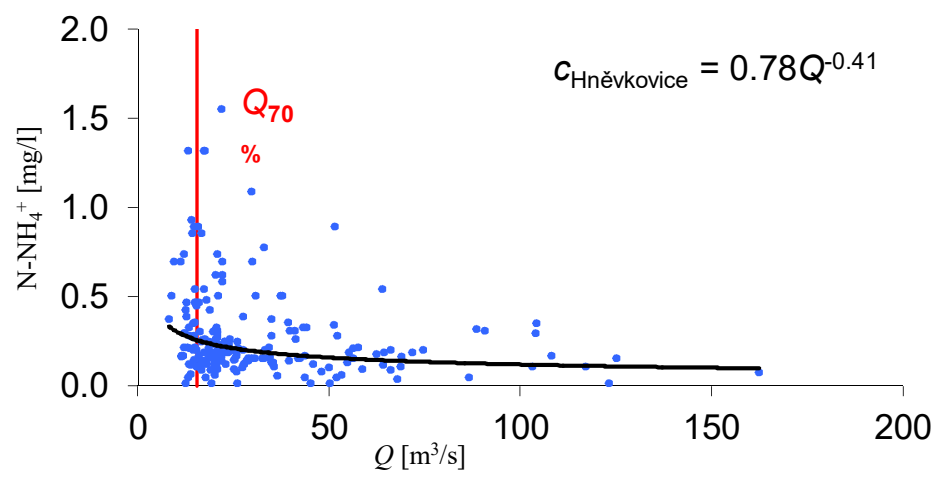

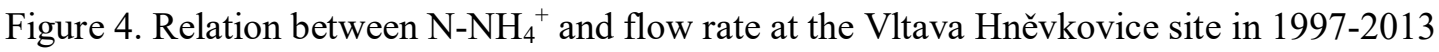

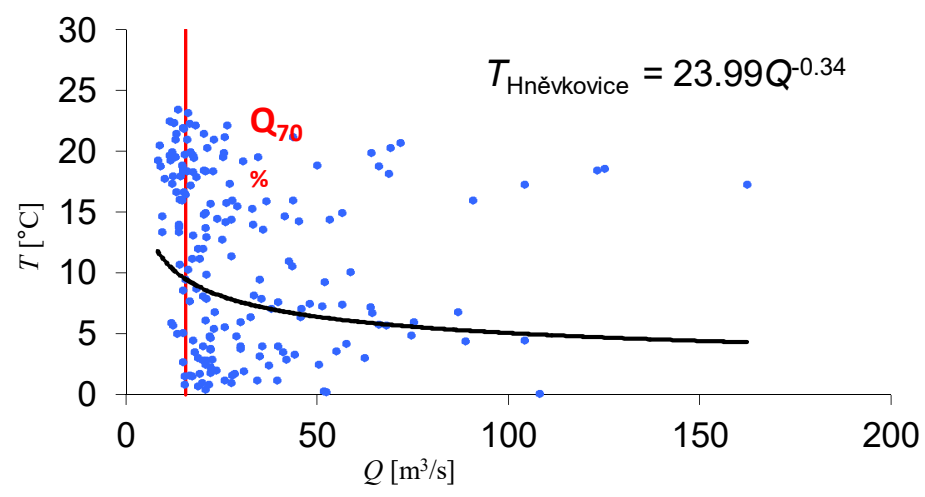

Figure 5. Relation between T and flow rate at the Vltava Hněvkovice site in 1997-2013

In Figures 6-7, the power relations of parameters $\mathrm{SS}$ and $\mathrm{N}_{-} \mathrm{NO}_{3}{ }^{-}$with the flow rate are compared for the following sites: Vltava Hněvkovice (influenced by the Lipno Dam operation), Lužnice Koloděje, Vltava Kořensko (influenced by the Lipno Dam operation), Otava Topělec and Vltava Solenice (downstream of the Orlík Reservoir).

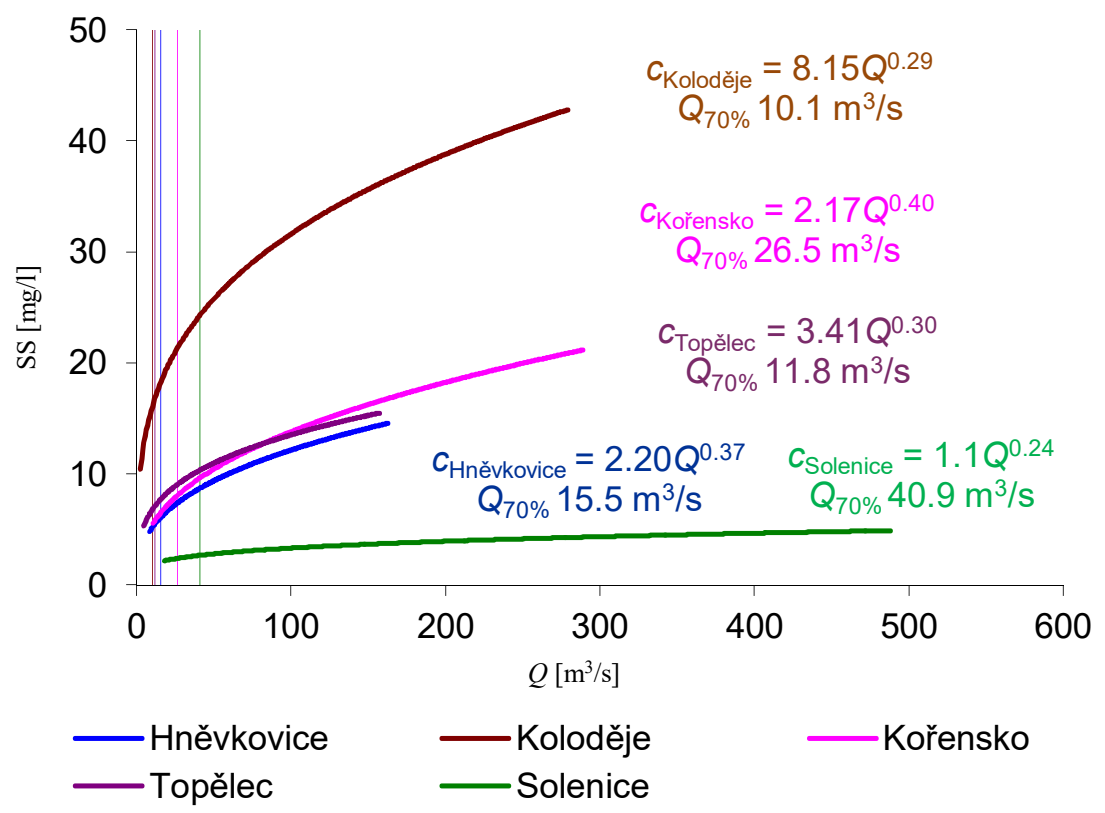

Figure 6. Comparison of relations between SS and flow rate at the Vltava Hněvkovice Lužnice Koloděje, Vltava Kořensko, Otava Topělec and Vltava Solenice sites in 1997-2013 


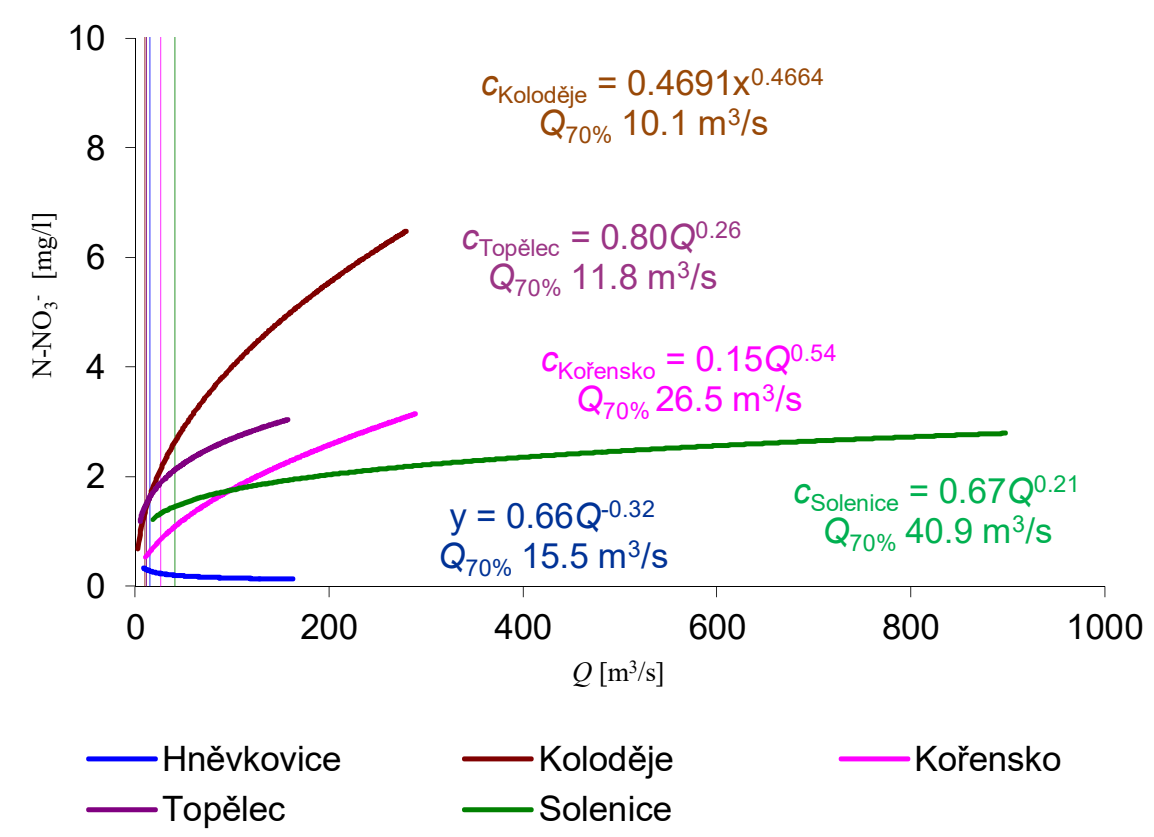

Figure 7. Comparison of relations between $\mathrm{N}_{-} \mathrm{NO}_{3}{ }^{-}$and flow rate at the Vltava Hněvkovice Lužnice Koloděje, Vltava Kořensko, Otava Topělec and Vltava Solenice sites in 1997-2013

In general, $\mathrm{N}_{-\mathrm{NO}_{3}}{ }^{-}$and $\mathrm{SS}$ parameters show the statistically most significant correlation with flow rate (a significant correlation in all assessed profiles), which supports the idea that the influence of point pollution sources is of a relatively low relevance in this case. Concerning seasonal changes of the $\mathrm{N}^{-\mathrm{NO}_{3}}{ }^{-}$parameter, the highest concentration values were detected in winter and spring (detailed results are not included due to the length of the paper). The $\mathrm{O}_{2}$ and $\mathrm{T}$ parameters show correlation on four out of five assessed sites.

Among the monitored parameters, no significant correlation with flow rate has been found for parameters of DIS and $\mathrm{K}^{+}$. For the DS, $\mathrm{COD}_{\mathrm{Mn}}, \mathrm{BOD}_{5}, \mathrm{Cl}^{-}, \mathrm{PO}_{4}{ }^{3-}, \mathrm{SO}_{4}{ }^{2-}, \mathrm{Ca}^{2+}$, $\mathrm{N}-\mathrm{NH}_{4}{ }^{+}$parameters, a statistically significant dependence was identified only for two out of all (five) sites.

In the long term, a further decline of point pollution sources' influence can be predicted as a consequence of construction of new waste water treatment plants and the intensification of the treatment process. This concerns mainly $\mathrm{COD}_{\mathrm{Mn}}, \mathrm{COD}_{\mathrm{Cr}}, \mathrm{BOD}_{5}, \mathrm{~N}-$ $\mathrm{NO}_{3}{ }^{-}, \mathrm{N}-\mathrm{NH}_{4}{ }^{+}, \mathrm{P}_{\mathrm{T}}$ a P-PO ${ }_{4}^{3-}$.

Further, average concentration values at lower and higher flow rates were assessed, whereas the dimension of the flow was delimited by the $Q_{70 \%}$ flow rate. In Figure 8, there is an example of water flow rates in days of sampling, including the $Q_{70 \%}$ flow rate, at the Vltava Hněvkovice site in 1997-2013. As the collected data showed, the number of samples taken during low flow rates was lower than the quantity of samples taken at high flows. The quantities of samples taken during low flow rates are presented in Table 2. The number of samples in particular years is within the range of $0-7$, which is $0-58 \%$ in relative units out of 12 samples taken conventionally every year. For the whole period of monitoring, the number of samples taken during low flow rates represents:

- $22.1 \%$ at the Vltava Hněvkovice site;

- $33.8 \%$ at the Lužnice Koloděje site;

- $24.8 \%$ at the Vltava Kořensko site;

- $31.9 \%$ at the Otava Topělec;

- $25.9 \%$ at the Vltava Solenice site. 
To assess the character of the pollution source, average values of the parameter concentrations were calculated for these two flow rate categories - for flow rate higher than $Q_{70 \%}$ and for flow rate lower than $Q_{70 \%}$. The ratios of these two categories of the parameter concentrations $\left(Q>Q_{70 \%} / Q<Q_{70 \%}\right)$ were evaluated.

The ratios $\left(Q>Q_{70 \%} / Q<Q_{70 \%}\right)$ correspond to the regression coefficient, which emerged from the power function parameters. That means that the ratio value around 1.0 corresponds to an insignificant dependence between the parameters (substance concentrations and others) and flow rate. Ratio value higher than 1.0 represents mean inverse dependencies and similarly, ratio value lower than 1.0 mean direct dependencies.

The parameter value ratios were in the range of:

- $\quad 0.7-1.4$ at the Vltava Hněvkovice site;

- $\quad 0.5-1.5$ at the Lužnice Koloděje site;

- 0.5-1.7 at the Vltava Kořensko site;

- $0.4-1.9$ at the Otava Topělec site;

- $0.6-1.5$ at the Vltava-Solenice site.

To illustrate the behaviour of the particular parameters, the ratios were arranged in ascending order in Figures 9-13. These figures show that the behaviour of the monitored parameters in particular profiles is similar but not the same.

Comparing to the behaviour of the studied parameters, ratios of average water flow rates for $Q>Q_{70 \%} / Q<Q_{70 \%}$ were 2.9 at the Vltava Hněvkovice site, 5.4 at the Lužnice Koloděje site, 3.6 at the Vltava Kořensko site, 3.5 at the Otava Topělec site and 3.5 at the Vltava Solenice site. In accordance with the expectations, the highest fluctuation of flow rates was found at the Lužnice Koloděje site, followed by the Otava Topělec site, since these two sites are not influenced by dam operations.

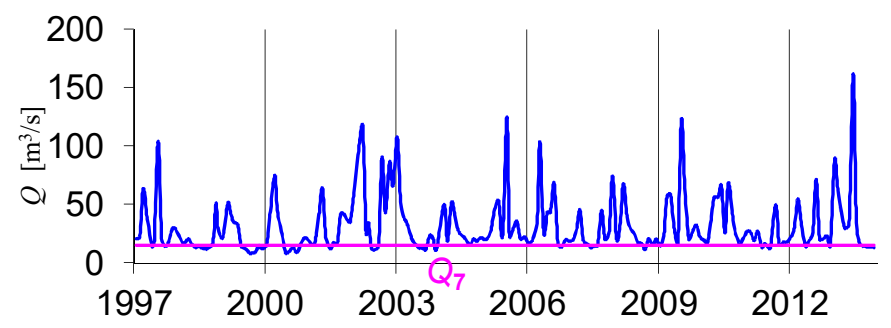

Figure 8. Water flow rates in days of sampling, including the $Q_{70 \%}$ flow rate, at the Vltava Hněvkovice site

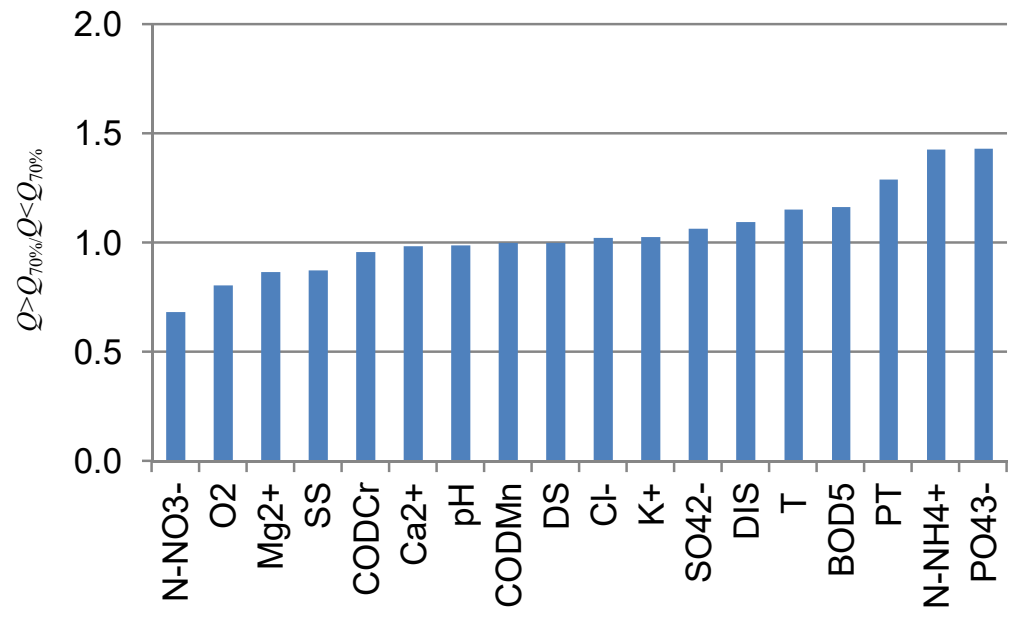

Figure 9. Ratios of average values for $Q>Q_{70 \%} / Q<Q_{70 \%}$ in ascending order at the Vltava Hněvkovice site in 1997-2013 


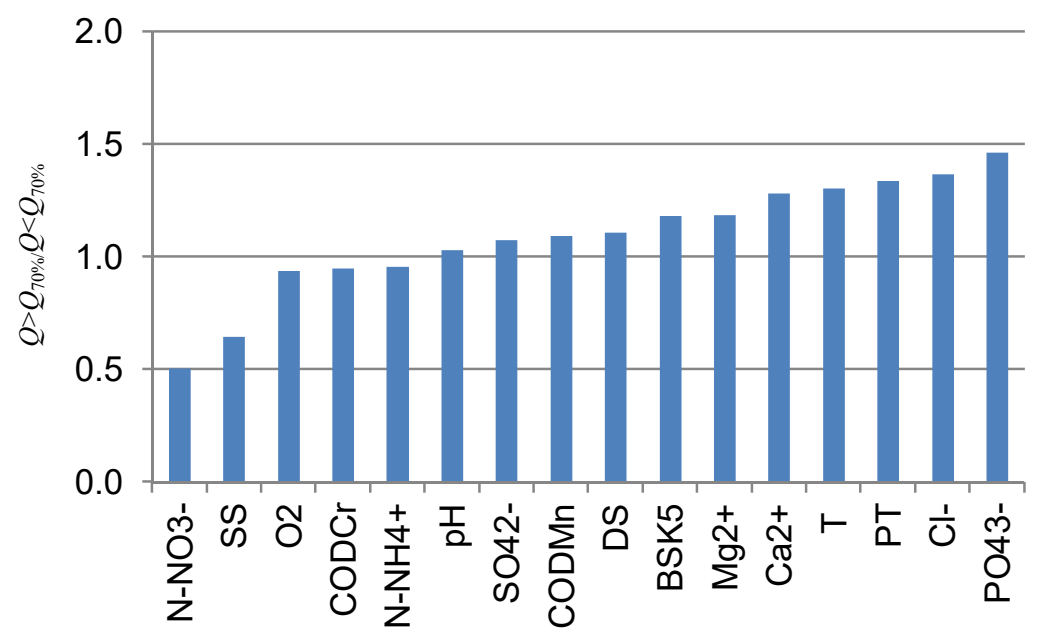

Figure 10. Ratios of average values for $Q>Q_{70 \%} / Q<Q_{70 \%}$ in ascending order at the Lužnice Koloděje site in 1997-2013

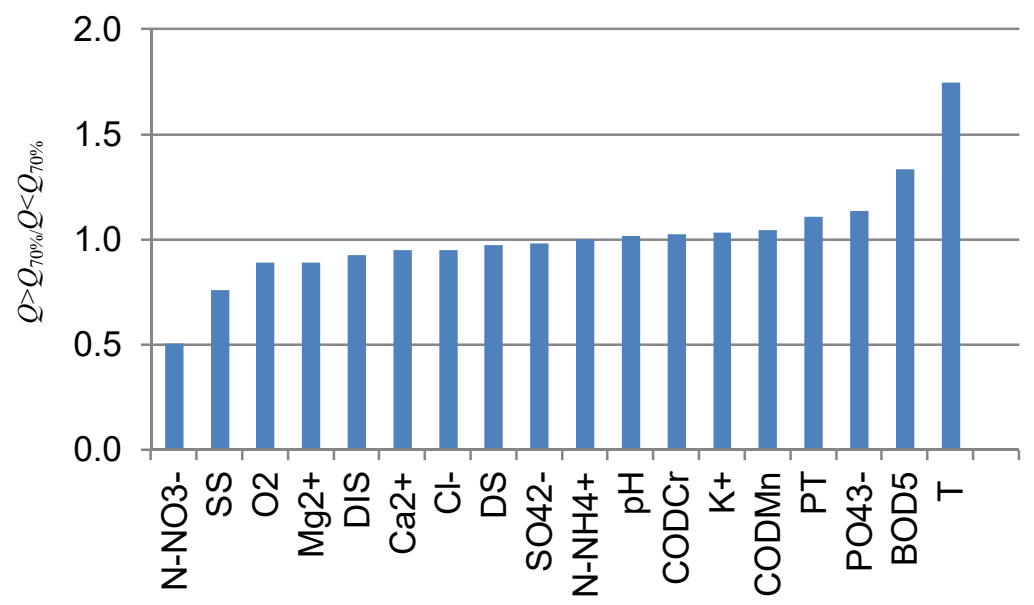

Figure 11. Ratios of average values for $Q>Q_{70 \%} / Q<Q_{70}$ in ascending at the Vltava Kořensko site in $1997-2013$

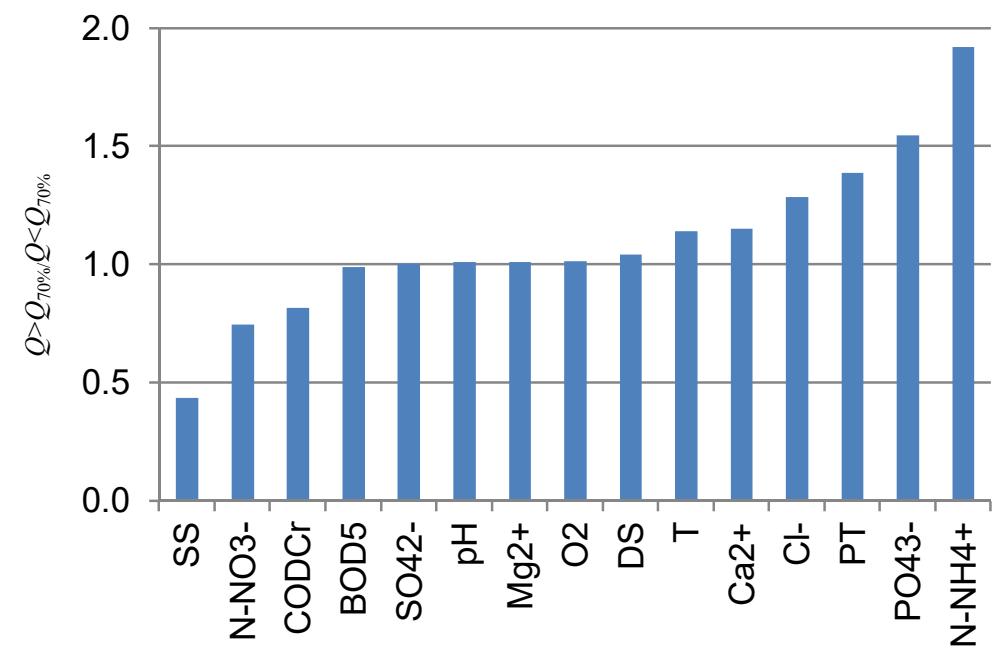

Figure 12. Ratios of average values for $Q>Q_{70 \%} / Q<Q_{70 \%}$ in ascending order at the Otava Topělec site in 1997-2013 


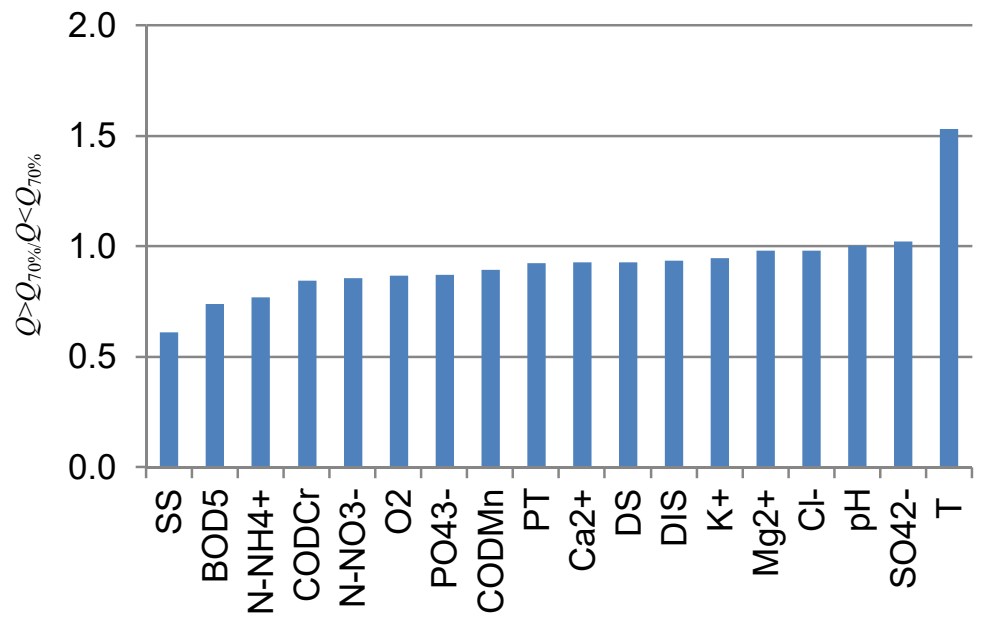

Figure 13. Ratios of average values for $Q>Q_{70 \%} / Q<Q_{70 \%}$ in ascending order at the Vltava Solenice site in 1997-2013

Table 2. Numbers of samples [n] taken during flow rates lower than $Q_{70 \%}$ at the Vltava Hněvkovice, Lužnice Koloděje, Vltava Kořensko, Otava Topělec and Vltava Solenice sites in particular years and averaged in the period of 1997-2013

\begin{tabular}{cccccc}
\hline Year & $\begin{array}{c}\text { Vltava } \\
\text { Hněvkovice }\end{array}$ & $\begin{array}{c}\text { Lužnice } \\
\text { Koloděje }\end{array}$ & $\begin{array}{c}\text { Vltava } \\
\text { Kořensko }\end{array}$ & $\begin{array}{c}\text { Otava } \\
\text { Topělec }\end{array}$ & $\begin{array}{c}\text { Vltava } \\
\text { Solenice }\end{array}$ \\
\hline 1997 & 2 & 4 & 3 & {$[\mathrm{n}]$} & \\
1998 & 5 & 5 & 6 & 4 & 2 \\
1999 & 7 & 7 & 7 & 7 & 5 \\
2000 & 5 & 7 & 6 & 6 & 5 \\
2001 & 2 & 2 & 2 & 4 & 6 \\
2002 & 3 & 3 & 2 & 0 & 3 \\
2003 & 4 & 7 & 5 & 5 & 2 \\
2004 & 1 & 3 & 1 & 4 & 6 \\
2005 & 0 & 2 & 1 & 5 & 2 \\
2006 & 1 & 3 & 1 & 4 & 3 \\
2007 & 3 & 6 & 4 & 3 & 5 \\
2008 & 2 & 6 & 2 & 3 & 5 \\
2009 & 1 & 4 & 2 & 3 & 2 \\
2010 & 0 & 1 & 0 & 3 & 0 \\
2011 & 3 & 3 & 3 & 4 & 4 \\
2012 & 2 & 3 & 2 & 3 & 0 \\
2013 & 4 & 3 & 3 & 2 & 2 \\
Average [\%] & 22.1 & 33.8 & 24.8 & 31.9 & 25.9 \\
\hline
\end{tabular}

To assess the character of the pollution source, the values of the $Q>Q_{70 \%} / Q<Q_{70 \%}$ ratios were compared to threshold values: average value ratios of the parameters which are higher than 11.1 indicate a prevailing influence of point sources, lower than 0.9 implies nonpoint sources of the pollution. These threshold values were designated with 
consideration of the uncertainties that can occur during the monitoring of water quality in surface water.

The $Q>Q_{70 \%} / Q<Q_{70 \%}$ ratio value lower than 0.9 , showing the effect of the nonpoint

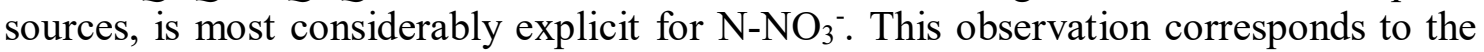
findings made in a detailed study [14], according to which pollution released into the Vltava Hněvkovice site, characterized as inorganic nitrogen, amounts to $325 \mathrm{t} / \mathrm{year}$. This equals to $23.5 \%$ of median of $\mathrm{N}_{-} \mathrm{NO}_{3}{ }^{-}$and $\mathrm{N}_{-} \mathrm{NH}_{4}{ }^{+}$amounts at this site in 2000-2009, which was 1,383.3 t/year [15]. A long term study [16] concerned with changes of chemical parameters in one of the Vltava River Reservoirs in 1959-1990 was engaged with impacts of nonpoint sources of nitrogen. Fraction of nitrogen run off caused by the nonpoint sources was in the range of $60-80 \%$. During extremely dry seasons, the significance of point sources increased. A significant direct power dependence of $\mathrm{NO}_{3}{ }^{-}$ concentration on flow rate was also observed at the major European river of Meuse [10]. For the parameters showing direct dependence of concentration on flow rate (for example nitrates), lower concentrations can be expected during low flows. On the other hand, for the parameters showing inverse dependence of concentration on flow rate, higher concentrations can be expected during low flows. That is supported by the results of a $\mathrm{Cl}^{-}$ concentration assessment, which showed inverse dependence at Lužnice Koloděje and Otava Topělec sites, similarly to the observations at the Meuse River [10].

\section{CONCLUSION}

The purpose of this study was to find the rules that influence the quality of river water during low and high flows occurring in dry and flood periods. Better understanding of this question led to identification of the character of the source for the studied water quality parameters. This may allow application of effective measures for preserving the appropriate water quality even during unfavourable conditions.

Relations between flow rates and water quality parameter values were analysed on examples of river sites in the Czech Republic in 1997-2013. As the assessment indicates, the ratio of average values during low flow rates (lower than $Q_{70 \%}$ ) and during high flow rates (higher than $Q_{70 \%}$ ) was lower than 0.9 for $\mathrm{N}_{-N_{3}}{ }^{-}, \mathrm{O}_{2}, \mathrm{SS}$ a $\mathrm{Mg}^{2+}$ at the Vltava Hněvkovice site. This means that for these parameters, direct dependence on flow rate was observed, which indicates a major influence of nonpoint pollution sources. In contrast, the ratio of average values higher than 1.1, which corresponds to inverse dependence on flow rate, indicating a predominance of point pollution sources, was found for the $\mathrm{BOD}_{5}, \mathrm{P}_{\mathrm{T}}, \mathrm{N}-\mathrm{NH}_{4}+, \mathrm{P}_{-} \mathrm{PO}_{4}{ }^{3-}$ and $\mathrm{T}$ parameters.

The results obtained in this study indicate that the behaviour of the particular water quality parameters cannot be generalized - it varies at different sites.

The assessment shows that in addition to the point pollution sources, the nonpoint sources influence the water quality, too. The nonpoint sources affect the $\mathrm{N}_{-} \mathrm{NO}_{3}{ }^{-}$a SS concentration most considerably. For further improvement of the prognosis of the quality parameters' behaviour in dry seasons, we recommend to continue the monitoring and assessment of water quality. It can be especially significant in conjunction with measures made at point and nonpoint pollution sources. Furthermore, verification of the determined behaviour of the water quality parameters is needed in relationship with real development of the climate change.

\section{ACKNOWLEDGEMENT}

This paper was prepared from the results of the project $\mathrm{SP} / 1 \mathrm{a} 6 / 125 / 08$ that has been sponsored by Ministry of the Environment of the Czech Republic. 


\section{REFERENCES}

1. Murdoch, P. S., Baron, J. S. and Miller, T. L., Potential Effects of Climate Changes on Surface-water Quality in North America, J. of the Am. Wat. Res. Ass., Vol. 36, pp 347366, 2000, http://dx.doi.org/10.1111/j.1752-1688.2000.tb04273.x

2. Buceti, G., Climate Change and Vulnerabilities of the European Energy Balance, J. of Sustain. Dev. of En., Wat. and Environ. Sys., Vol. 3, No. 1, pp 106-117, 2015, http://dx.doi.org/10.13044/j.sdewes.2015.03.0008

3. Shrestha, R. R., Dibike, D. B. and Prowse, T. D., Modeling Climate Change Impacts on Hydrology and Nutrient Loading in the Upper Assiniboine Catchment, J. of the Am. Wat. Res. Ass., Vol. 48, No. 1, pp. 74-89, 2012, http://dx.doi.org/10.1111/j.17521688.2011.00592.x

4. Johnson, T., Butcher, J., Deb, D., Faizullabhoy, M., Hummel, P., Kittle, J., McGinnis, S., Mearns, L. O., Nover, D., Parker, A., Sarkar, S., Srinivasan, R., Tuppad, P., Warren, M., Weaver, C. and Witt, J., Modeling Streamflow and Water Quality Sensitivity to Climate Change and Urban Development in 20 U.S. Watersheds, J., J. of the Am. Wat. Res. Ass., Vol. 51, No. 5, pp 1321-1341, 2015, http://dx.doi.org/10.1111/17521688.12308

5. Vlnas, R. et al., Temporal and Spatial Variations of Hydrological Drought under Climatic Change Conditions in the Czech Republic (Časová a plošná variabilita hydrologického sucha v podmínkách klimatické změny na území České republiky), TGM WRI Report, Prague, 2010 (in Czech).

6. Momblanch, A., Managing Water Quality under Drought Conditions in the Llobregat River Basin, Sci. of the Tot. Env., Vol. 503-504, pp 300-318, 2015, http://dx.doi.org/10.1016/j.scitotenv.2014.06.069

7. Mosley, L. M., Drought Impacts on the Water Quality of Freshwater Systems; Review and Integration, Earth-Scie. Rev., Vol. 140, pp 203-214, 2015, http://dx.doi.org/10.1016/j.earscirev.2014.11.010

8. Caruso, B. S., Temporal and Spatial Patterns of Extreme Low Flows and Effects on Stream Ecosystems in Otago, New Zealand, J. of Hyd., Vol. 257, pp 115-133, 2002, http://dx.doi.org/10.1016/S0022-1694(01)00546-7

9. Somville, M. and De Pauw, N., Influence of Temperature and River Discharge on Water Quality of the Western Scheldt Estuary, Wat. Res., Vol. 16, pp 1349-1356, 1982, http://dx.doi.org/10.1016/0043-1354(82)90213-5

10.van Vliet, M. T. H. and Zwolsman, J. J. G., Impact of Summer Droughts on the Water Quality of the Meuse River, J. of Hyd., Vol. 353, pp 1-17, 2008, http://dx.doi.org/10.1016/j.jhydrol.2008.01.001

11.Balance of Released Waste Water in 2009 (Bilance vypouštěných odpadních vod v roce 2009), TGM WRI Data, 2010 (in Czech).

12.Operating Regulations of the Water Management Structure Hněvkovice - Kořensko on the Vltava River (Manipulační řád vodního díla Hněvkovice-Kořensko na řece Vltavě), Regional Authority České Budějovice (no. 4022/94/95-231/2-Si, 1996, revision CVD 26. 3., 2009 (in Czech).

13.Brzáková, J., Hydrological data (Hydrologická data), CHMI, 2009 (in Czech).

14.Nesměrák, I., Possibilities of Improvement of Water Quality in the Vltava River in the Hněvkovice and Kořensko Profile (Možnosti zlepšení jakosti vody ve Vltavě v profilu Hněvkovice a Kořensko), Study, Prague, 2009 (in Czech).

15.Hanslík, E., Monitoring and Assessment of Surface and Ground Water Quality and its Changes in Connection to Impact of Construction and Operation of the Temelín Nuclear Power Plant onto its Vicinity (Sledování a hodnocení jakosti povrchových a podzemních vod a jejich změn v souvislosti s vlivem výstavby a provozu jaderné elektrárny Temelín na její okolí), TGM WRI Report, 2010 (in Czech). 
16.Procházková, L., Blažka, P. and Kopáček, J., Impact of Diffuse Pollution on Water Quality of the Vltava River (Slapy Reservoir), Czech Republic, Wat. Sci. and Tech., Vol. 33, pp 145-152, 1996, http://dx.doi.org/10.1016/0273-1223(96)00224-7

Paper submitted: 18.08.2015

Paper revised: 22.10.2015

Paper accepted: 24.10.2015 